\title{
PANDEMI AS A REASON FORCE MAJEURE IN CONTRACT PROCUREMENT OF GOODS / GOVERNMENT SERVICES
}

\author{
Fitri Yanni Dewi Siregar \\ University of Medan Area \\ fitriyannidewisrg@gmail.com
}

\begin{abstract}
Procurement of goods and services is an effort to obtain the desired goods and services by doing it on the basis of logical and systematic thinking (the system of thought), following applicable norms and ethics, based on standard procurement methods and processes. However, when a pandemic event occurs, many activities of every person and institution related to the procurement of goods / services become impeded. The occurrence of the Covid-19 pandemic required the state to prioritize the safety of the population, and therefore it was necessary to provide sufficient budget. This is what causes a "budget shift" which then makes the budget for procurement of goods I services significantly reduced, or even no more. Presence of Presidential Decree No. 12 of 2020concerning the Determination of Non-Disaster Spread of Corona Virus Disease 2019 (Covid-19) was not intended to make Covid-19 as a direct reason to cancel the contract. This becomes the reason and entrance for renegotiation with the reason that force majeure can certainly be based on Pasal 1244, Pasal 1245, and especially Pasal 1338 of the Civil Code. The legal effect of the presence of Presidential Decree on the Establishment of non-natural disasters Spreading Corona Virus Disease 2019 (Covid-19) against the contract goods / services procurement of government is s epanjang condition of force majeure are met, the KDP has a legitimate basis in stopping the process of selection and contracting process based on propriety and justice and the principle of budget availability.
\end{abstract}

Keywords: Force Majeure, Procurement Contract.

Copyright @2020 NLR. All right reserved.

\section{INTRODUCTION}

Procurement of goods and services has a major contribution to the country's economy. In the context of fiscal policy, the procurement of goods and services aims to drive the economy by growing jobs, increasing competitiveness, and increasing economic growth. Procurement of goods and services whose financing is partly or wholly sourced from the State Revenue and Expenditure Budget / Regional Revenue and Expenditure Budget (APBN/APBD) is a procurement of service goods in the government environment that aims to provide public goods / services. ${ }^{1}$

Procurement of goods and services is an effort to obtain the desired goods and services by doing it on the basis of logical and systematic thinking ( the system of thought), following applicable norms and ethics, based on standard procurement methods and processes. ${ }^{2}$ As for one of the procurement processes, it is marked by an

${ }^{1}$ Sutedi, Adrian, Aspek-Aspek Hukum Pengadaan Barang dan Jasa dan Berbagai Permasalahannya, (Jakarta: Sinar Grafika, 2008), p 46.

${ }^{2}$ Ibid., p. 5. 


\section{LAW REVIEW $\begin{aligned} & \text { E-ISSN:2722-3663 } \\ & \text { Volume } 1 \text {, Issue I, May 2020 }\end{aligned}$}

agreement. Goods / services procurement agreements or known as government goods / services procurement contracts (procurement contracts) are basically born as an implementation of the principle of freedom of contract between the parties involved in the contract. ${ }^{3}$

In a contractual relationship each party that agrees to an agreement is obliged to carry out all the provisions contained in the Agreement. The parties must fulfill their obligations and obtain their rights regulated in the agreement. Just like an agreement in general, force majeure clause is a general matter that is usually poured into the Agreement. The force majeure experienced

by providers (contractors / suplier) either due to natural disasters, non-natural disasters, strike, discontinue goods, and so on another. But now there is a new phenomenon that is the emergence of a virus called Corona Virus Disease 2019 (Covid-19) which is a type of disease that causes public health emergencies.

In order to prevent the spread of Covid-19, the Government took steps to establish the Covid-19 pandemic as a national disaster and to encourage the public to carry out physical distancing and work / learn from home. This Government Appeal was followed by the issuance of a number of legal umbrellas. The impact of the occurrence of this pandemic ultimately

3 Purwosusilo, Aspek Hukum Pengadaan Barang dan Jasa, (Jakarta: Prenada Media Group, 2014), p. 227. obliges the state to prioritize the safety of the population, and therefore needs to provide sufficient budget. This is what causes a "budget shift" which then makes the budget for procurement of goods / services significantly reduced, or even no more. On the other hand, of course the providers in many cases also experienced obstacles in fulfilling their obligations due to this pandemic. Policies to ockdown or social distancing also create a business entity disturbed. It is estimated that many companies or people can not keep their promises. For example, shipping goods to a country that is implementing a lockdown. In other words, it is likely that many contracts, agreements, business transactions or activities have been delayed due to the spread of the Covid-19 outbreak.

In the context of the agreement, what if the phenomenon makes one party unable to fulfill its obligations? In the perspective of Civil law, of course, those who cannot carry out their obligations can be qualified to have carried out "broken promises" or "negligent" in carrying out their obligations". The legal implications are clearly regulated in Pasal 1243 of the Civil Code which in essence regulates the obligation to compensate for losses arising from the non-fulfillment of an Agreement. However, when referring to Pasal 1244 and 1245 Civil Code, in essence, these two Pasals show that in a situation compelling a negligent party to carry out its obligations can be released from the responsibility to compensate for losses arising from the non- 


\section{LAW REVIEW $\begin{aligned} & \text { E-ISSN: 2722-3663 } \\ & \text { Volume }, \text { Issue 1, May 2020 }\end{aligned}$}

implementation

of

an

agreement.

Based on this, the following will explain whether the co-19 pandemic can be qualified as a cause of force majeure, and how its implications for government goods and services procurement contracts.

\section{METHODOLOGY}

Legal research is a process to find the rule of law, legal principles, and legal doctrines to address the legal issues at hand. ${ }^{4}$ The type of legal research used in this study is normative juridical. The data used are secondary data using primary legal materials, secondary legal materials, and tertiary legal materials.

\section{DISCUSSION}

\section{The Covid-19 pandemic is qualified} as a cause of force majeure

Force majeure clause is a common thing that is usually poured into the Agreement. Force Majeure itself is etymologically derived from the French language which means "greater power". In the context of civil law force majeure is a condition where a person cannot carry out his obligations not because he is intentional or negligent, but because there are things that are beyond his power and influence him not to carry out his obligations (overmacht). ${ }^{5}$ Mochtar Kusumaatmadja stated that force majeure or vis major could be accepted

$\begin{array}{cccc}4 & \text { Marzuki, } & \text { Peter } & \text { Mahmud, } \\ \text { Penelitian } & \text { Hukum, } & \text { (Jakarta: } & \text { Kencana }\end{array}$ Prenada Media Group, 2005), p. 35.

${ }^{5}$ bplawyers,co,id, accessed on 15 May (2020), as an excuse for not fulfilling the implementation of obligations due to the loss / disappearance of the object or purpose that was the subject of the agreement. This situation is aimed at the physical and legal implementation, not because it is only a difficulty in carrying out obligations. Mieke Komar Kantaatmadja gave a similar view: ${ }^{6}$

1. Changes to a situation do not occur at the time the agreement is formed.

2. The change is about a condition that is fundamental to the agreement.

3. Such changes cannot be predicted in advance by the parties.

4. As a result of these changes must be radical, thus changing the scope of obligations that must be carried out according to the agreement.

5. The use of the principle cannot be applied to border agreements and also changes in circumstances due to violations committed by the party who filed the claim.

Force majeure is intended to provide protection for one of the injured parties in an agreement, provided that the objective conditions and / or subjective conditions have been fulfilled as a force majeure .

Narrowlyforce majeure is indeed identical with natural events (act of god) which causes a person to not be able to carry out his obligations on the grounds of a disaster. As for what is commonly referred to as a force majeure condition is a condition where one party cannot perform its obligations

6 Purwanto, Harry, Keberadaan Asas Rebus Sic Stantibus Dalam Perjanjian Internasional, Jurnal Mimbar Hukum Edisi Khusus, (November 2011). 
not because of intentions or intentions but rather events that make it unable to carry out these obligations. ${ }^{7}$ Because in the case of the corona pandemic case the Indonesian government issued a rule, the corona context force majeur was included in the special category (act of human).

\section{Elements of Force Majeure}

The arrangement of force majeure in Indonesia is contained in Pasal $1244^{8}$ and $1245^{9}$ Civil Code, but if it is examined further the provisions emphasize more on how to reimburse costs, losses and interest but can be used as a reference as a force majeure arrangement . The force majeure clause provides protection provided against losses caused by fire, flood, earthquake, rainstorm, hurricane, (or other natural disasters), power outages, catalyst damage, sabotage, war, invasion, civil war, rebellion, revolution, military coups, terrorism, nationalization, blockades, embargoes,

${ }^{7}$ www,hukumonline,com, (accessed on 15 May (2020).

${ }^{8}$ Article 1244 Civil Code "If there is a reason for that the debtor must be punished to replace the costs, loss and interest, if he doesn't prove it, that the matter was not carried out or not at the right time for the agreement, caused by an unexpected thing, also cannot be held accountable to him, all of that too if bad faith is not on his side.

${ }^{9}$ Article 1245 Civil Code: "It is not a fee, loss and interest must be replaced, if due to a forced condition (overmacht) or due to an unintentional situation, the debtor is unable to give or do something that is required, or because the same things have done prohibited acts." labor disputes, strikes and sanctions against a government.

The elements which state how a situation can be declared as a force majeure usually have a commonality in every rule of law and court decisions in every interpretation of this word. These elements include: First, events that occur due to a natural event. Second, unexpected events will occur. Third, events that show the inability to carry out obligations towards a contract both in whole or only for a certain time. ${ }^{10}$

When viewed in terms of the period of validity of conditions that cause force majeure to occur, force majeure can be distinguished into:

a. Permanent force majeure

Aforce majeure is said to be permanent if at all time an achievement issued by a contract is impossible. For example if the goods which are the object of the contract are destroyed beyond the debtor's mistake.

b. Temporary Force Majeure

Conversely, a force majeure is said to be temporary if the fulfillment of the achievement of the contract is not possible for a while, for example because certain events occur, where

10 Melis, Werner, Force Majeure and Hardship Clauses in International Commercial Contracts in View of the Practice of the ICC Court of Arbitration, Report presented by the author at an ICC Seminar an East West Arbitration held in Paris an December 6-9, 1983, pg, 215, perhatikan juga Agri Chairunisa Isradjuningtias, Force Majeure (Overmacht) Dalam Hukum Kontrak (Perjanjian) Indonesia, p. 149. 


\section{LAW REVIEW $\begin{aligned} & \text { E-ISSN: } 2722-3663 \\ & \text { Volume } 1 \text {, Isue 1, May 2020 }\end{aligned}$}

after the event stops, the achievement can be fulfilled.

As it is known that an important consequence of the existence of force majeure is who has to bear the risk of an event that is a force majeure. Pasal 1237 KUHPerdata (Civil Code): "Dalam hal adanya perikatan untuk memberikan suatu kebendaan tertentu, maka sejak perikatan-perikatan dilahirkan, benda tersebut menjadi tanggungan pihak kreditur". From the provisions in Pasal 1237 of the Civil Code it is explained that if there is aforce majeure on a unilateral contract, then the risk is borne by the recipient of the achievement (creditor). Unless the debtor is negligent in providing performance, where since the negligence is at the risk of the grantor (the debtor). ${ }^{11}$

\section{Pandemic as a reason for force majeure}

The presence of a contract forms a private entity between the parties in which each party has a juridical right to demand implementation and compliance with restrictions agreed upon by the other party voluntarily. ${ }^{12} \mathrm{~A}$ legal relationship that is born through a contract does not always carry out its aims and objectives, the situation can occur as a result of a default either by a creditor or debtor, coercion, misrepresentation, cheating, or circumstances that force or are known as force majeure or known in

${ }^{11}$ Pasal 1237 Civil Code.

12 Hardjowahono, Bayu Seto, (Ketua Tim), Naskah Akademik Rancangan Undang Undang Hukum Kontrak, Badan Pembinaan Hukum Nasional Kementerian Hukum Dan Ham RI, (2013), p. 3,
Indonesian law with overmacht. The consequences arising from this situation cause an agreement (contract) can be canceled and null and void by law. ${ }^{13}$

If you reflect on the current conditions, can the Covid19 outbreak qualify as a force majeure? answering these questions consider the provisions of Pasal 1245 that tar was included in the Book III of the Civil Code that are complementary agreements. That is, as long as the parties do not regulate otherwise, the provisions of Book III, particularly those related to force majeure, will apply. If an agreement for example regulating a pandemic is not part of a force majeure, then it must be so. "However, if the parties do not agree, then the pandemic can be considered a force majeur e ,"

Although Covid-19 may be qualified as aforce majeure, it is not enough to be able to prove that one of the parties in the agreement can be

13 Erawati, E., Budiono, H, Penjelasan Hukum Tentang Kebatalan Perjanjian, Nasional Legal Reform, (Jakarta: Program-Gramedia, 2010), p. 5, The 'cancel' theme listed the form of the derivation, i,e, cancel and cancel, there is no written form of ,cancellation', These two things are different from valid terms, whose form of derivation is validating, endorsement, and validity, Seems that, the derivation form 'cancellation' is considered unusual in Indonesian, in contrast to abs validity 'which may be more widely used in spoken and written languages, However, because in Agreement Law there are always problems with agreements that can be canceled and null and void by law, so that the contents of this restatement include both, the term used is 'cancellation' as a noun meaning 'void nature', 
released from the responsibility of making compensation because it cannot carry out its obligations due to force majeure. The covid-19 pandemic is a non-natural disaster. To use this event as a force majeure to avoid fulfilling obligations or defending a lawsuit by a creditor, further evaluation is needed. The application of clauses is subjective. Not all debtors experience force majeure despite a pandemic. The application must be done by analyzing case by case. This is done because a debtor may indeed be unable to fulfill obligations (prevented) because of the existence of this pandemic, but it is also very possible that a pandemic cannot be used by a debtor as an excuse to not fulfill its obligations because a pandemic has no effect in fulfilling its obligations.

Thus, the question whether a debtor experiences force majeure, it is necessary to make an assessment of the fulfillment of obligations whether it can be prevented or not. Only positive (prevented) answers indicate the debtor is experiencing force majeure. Conversely, if the fulfillment of obligations is still possible by the debtor, then the argument of force majeure cannot be used. If the Covid-19 pandemic event must also be an unexpected event at the time the agreement was made. This means that if an agreement is made at the time the outbreak is spreading and infecting, outbreak and lockdown events cannot be used as an excuse as a force majeure.

Consequences of the Covid19 Pandemic Law on government

\section{procurement of goods and services contracts .}

Government / Government Goods

I Services Procurement hereinafter referred to as Goods / Services Procurement is the activity of Procurement of Goods / Services by the Ministry / Institution / Regional Apparatus funded by the APBN / APBD whose process has been from the identification of needs, up to the handover of the work of goods / services by ministries / agencies / units other regional / institutional work (hereinafter referred to as $\mathrm{K} / \mathrm{L} /$ D / I) whose process starts from the planning of needs until the completion of all activities to obtain goods / services. ${ }^{14}$

Goods / Services Procurement Contract, hereinafter referred to as Contract, is a written agreement between the PA / KPA / PPK and the Goods / Services Provider or the SelfImplementer. ${ }^{15}$ Basically the contract was born as an implementation of the principle of freedom of contract between the parties involved in the contract. $^{16}$ Contracts for the procurement of government goods and services represent the free will of the government and the goods / service provider to determine something that is fair to both parties. It's just that the

${ }^{14}$ Article 1 number 1 Presidential Decree No, 16 of 2018 concerning Procurement of Government Goods / Services.

${ }^{15}$ Article 1 number 43 Presidential Decree No, 16 of 2018 concerning Procurement of Government Goods / Services.

\footnotetext{
${ }^{16}$ Purwosusilo, Op, Cit., p. 227,
} 
principle of freedom is limited by state provisions, in this case the laws and regulations governing the contract of procurement of government goods / services. This is also supported by the opinion of Mariam Darul Badrulzaman, the standard agreement established by the government. ${ }^{17}$

Procurement contracts have a unique character. Unlike the contract in general. Procurement contract is a type of contract that is routine because it is related to state / regional financial expenditure every year, and is mass. It involves a very large amount of money (budget) and a large number of contracts and a variety of characters.

One of the fundamental aspects of this type of contract is that when the contract is signed, the Commitment Making Officer (PPK) as the party representing the government, must ensure the availability of the budget. PPK is prohibited from entering into agreements or signing contracts with providers, in the case that there is no budget available or there is not enough available budget. This is the principle of budget availability. Thus the budget document (DPA) becomes an important instrument for PPK before signing a contract. Revenue and expenditure budgets, both APBN / APBD, are basically still estimates (predictions). The revenue figures contained in the budget document may be missed. As a result, there are no funds to finance the project while the contract has been signed. This can be

17 Badrulzaman, Mariam Darus, Kumpulan Pidato Pengukuhan, (Bandung: Alumni, 1981), p 99-100. seen in some cases of multi-year contracts (multyyears) which had to be stopped halfway because of predictions reception plummeted. ${ }^{18}$

The Presence of Presidential Decree No. 12/2020 concerning Determination of Non-Disaster in the Spread of Corona Virus Disease 2019 (Covid-19) As a National Disaster (Keppres 12/2020) plays an important role in the implementation of procurement when a pandemic occurs. Not called the wordforce majeure in this decree. But with the determination that co-19 is a nonnatural disaster, contractual obligations cannot be fulfilled because co-19 can be used as a basis for force majeure as long as the conditions are met.

Determine that the contract can be terminated or continued with contract changes. This shows that this regulation applies the principle that force majeure can be permanent, it can also be temporary. If the force majeure is permanent the contract can be terminated. Meanwhile, if the force majeure is temporary, the contract can be changed. But the regulation does not regulate the situation when there are obstacles when the process is still in the election stage, SPPBJ is published but the contract has not been signed. Need to be given an explanation of this. Our (legal) engagement system knows no rules about canceling negotiations or negotiations. This is because we are

18 Simamora, Y, Sogar, Force Majeur Dalam Kontrak Pengadaan Barang/Jasa Pemerintah, Guru Besar Fh Unair Surabaya, Ketua Asosiasi Pengajar Hukum Keperdataan, p. 2. 
still using the rule of the Dutch colonial legacy law, the Civil Code (BW) which is already "old". ${ }^{19}$

In the context of procurement contracts, consideration should be given to the principle of budget availability. In the contract law doctrine that is now commonly followed, there is accountability when one terminates negotiations halfway without proper reason. Netherland Burgerlijk Wetboek (NBW) regulates 3 (three) situations related to termination of negotiations namely: ${ }^{20}$

1. The parties are free to stop negotiations without any obligation to pay compensation.

2. Based on principles of decency and justice, one of the parties are free to terminate the negotiations but is obliged to pay compensation for expenditures; and

3. Based on decency and justice, one of the parties can no longer break off negotiations.

If this is violated then the other party has the right to demand not only costs for expenses, but also the expected benefits. $\mathrm{D}$ ith the explanation above, then:

1. When procurement is still in the precontract (election) stage, PPK can request the working group so that the electoral process is terminated;

2. In situations where a winner has been determined, while the SPPBJ has not yet been issued, the PPK has sufficient reasons not to issue the SPPBJ. The PPK can declare the

\footnotetext{
${ }^{19} \mathrm{Ibid}$.

${ }^{20}$ Ibid.
}

election null and void because the SPPBJ cannot be issued because the contract cannot be signed because there is no certainty about the availability of the budget.

3. J ika has published SPPBJ CO, CO may cancel the SPPBJ the same reasons as the number 2 .

4. J ika contract has been signed, the CO may apply Pasal 55 of Presidential Decree 16/2018: terminate the contract if the contract is no longer possible to carry out, or change the contract either in relation to duration, volume and the type and technical specifications.

In the implementation of contract fulfillment, there can be obstacles due to a condition that is experienced by the supplier of goods / services which is beyond his control and cannot be predicted beforehand, so that the goods / service provider cannot complete the work on time. Related to contract failure, it can occur due to internal factors and external factors that affect the existence of the contract / agreement.

In the event that after making adjustments to prioritize the use of certain activity budget allocations and / or changes in budget reallocation in the APBD as a follow-up to the determination of public health emergencies as a national disaster there is a need for procurement of goods / services in the context of handling COVID-19, but local governments cannot make payments in the Fiscal Year 2020 as a result of liquidity difficulties that could result in 
exceeding the expenditure budget limit, the local government recognizes it as a debt to the second party and is budgeted back in the following fiscal year based on the provisions of the legislation. ${ }^{21}$

If after adjusting prioritizing the use of certain activities and / or changes in budget reallocation in the APBD as a follow-up to the determination of public health emergencies as a national disaster, there are several goods / service procurement activities that have already been signed by contracts, the Regional Government implements policies based on Pasal 55 of Presidential Regulation Number 16 of 2018 concerning Procurement of Government Goods / Services, including: ${ }^{22}$

a. for work that is included in the priority program according to the APBD in 2020, especially to ensure the continuity of the fulfillment of basic community services that cannot be postponed, the contract continues until all work is completed and payment is charged at 2020 or 2021;

b. optimizing contracts by adjusting the scope of work to the available budget in 2020;

21 Head of the Republic of Indonesia Government Goods / Services Procurement Policy Agency, Joint Circular, Number 11 of 2020 concerning the FollowUp on Contracts for Goods / Services Administration in Adjusting the Budget for Revenue and Expenditures in 2020 As an Impact of the State of the Community Health Emergency as a National Disaster Corona Virus Disease-2019 (Covid-19).

${ }^{22}$ Ibid. c. termination of contract permanently, for work that can be postponed for completion; and

d. temporary termination of contracts for work that can be delayed.

To avoid any legal implications in the future, if there is a change in the conditions as referred to in number 3 above, so that Gubernur / Regent of the City may report the procurement of goods / services to the Head of the Government Goods / Services Procurement Policy Agency and be copied to the Minister of Home Affairs through Director General of Regional Financial Development.

\section{CONCLUSION}

The Covid-19 pandemic has become a non-natural disaster in Indonesia. With the Presidential Decree No. 12 of 2020 concerning Determination of Non-Disaster Spread of Corona Virus Disease 2019 (Covid19) is not intended to make Covid-19 as a direct reason to cancel the contract. This becomes the reason and entrance for renegotiation with the reason that force majeure can certainly be based on Pasal 1244, Pasal 1245, and especially Pasal 1338 of the Civil Code.

The Presence of Presidential Decree No. 12/2020 concerning Determination of Non-Disaster in the Spread of Corona Virus Disease 2019 (Covi d-19) As a National Disaster plays an important role in the implementation of procurement when a pandemic occurs. The determination that Covid-19 is a non-natural disaster can not be fulfilled by contractual obligations because Covid-19 can be used as the basis forforce majeure 


\section{LAW REVIEW ${ }^{\text {E-ISSN: 2722-3663 }}$

as long as the conditions are met. Therefore, KDP has a valid basis for stopping the selection process and the contract process based on propriety and fairness and the principle of budget availability.

\section{REFERENCES}

Badrulzaman, Mariam Darus., Kumpulan Pidato Pengukuhan, Bandung: Alumni, 1981.

bplawyers.co.id, accessed on 15 May (2020).

Code of Civil law.

Erawati, E., Budiono, H., Penjelasan Hukum Tentang Kebatalan Perjanjian. Nasional Legal Reform, Jakarta: ProgramGramedia, 2010.

Hardjowahono, Bayu Seto., (Ketua Tim). Naskah Akademik Rancangan Undang Undang Hukum Kontrak, Badan Pembinaan Hukum Nasional Kementerian Hukum Dan Ham RI. (2013).

Head of Goods / Services Procurement Policy Agency of the Government of the Republic of Indonesia, Joint Circular Letter, Number 11 Year 2020 Regarding Follow-Up on Goods / Service Procurement Contracts to Adjusting the 2020 Budget of Revenue and Expenditures as a Impact of the State of the Community Health Circumstances | Corona Nastonal Disaster Y / Rus D / Sease-2019 (Covid19).Keputusan Presiden No. 12/2020 tentang Penetapan Bencana Nonalam Penyebaran Corona Virus Disease 2019 (Covid-19) Sebagai Bencana Nasional.
Marzuki, Peter Mahmud., Penelitian Hukum. Jakarta: Kencana Prenada Media Group, 2005.

Melis, Werner., Force Majeure and Hardship Clauses in International Commercial Contracts in View of the Practice of the ICC Court of Arbitration. Report presented by the author at an ICC Seminar an East West Arbitration held in Paris an December 6-9. 1983. pg. 215. perhatikan juga Agri Chairunisa Isradjuningtias.

Force Majeure (Overmacht) Dalam Hukum Kontrak (Perjanjian) Indonesia.

Presidential Decree No. 16 of 2018 concerning Procurement of Government Goods / Services.

Purwanto, Harry., Keberadaan Asas Rebus Sic Stantibus Dalam Perjanjian Internasional. Jurnal Mimbar Hukum Edisi Khusus. (November 2011).

Purwosusilo. Aspek Hukum Pengadaan Barang dan Jasa. Jakarta: Prenada Media Group, 2014.

Simamora, Y. Sogar. Force Majeur Dalam Kontrak Pengadaan Barang/Jasa Pemerintah. Guru Besar Fh Unair Surabaya. Ketua Asosiasi Pengajar Hukum Keperdataan.

Sutedi, Adrian. Aspek-Aspek Hukum Pengadaan Barang dan Jasa dan Berbagai Permasalahannya. Jakarta: Sinar Grafika, 2008.

www.hukumonline.com. accessed on 15 May (2020). 